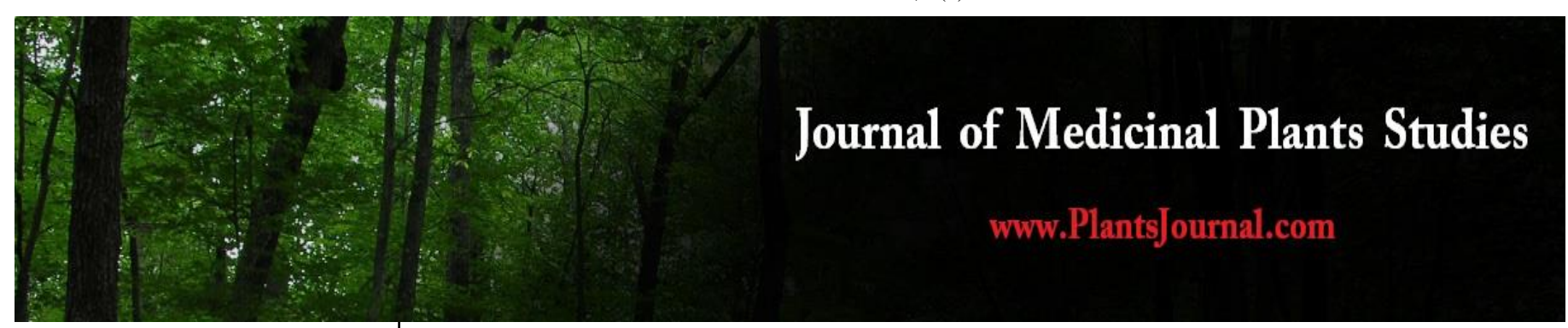

ISSN (E): 2320-3862

ISSN (P): 2394-0530

NAAS Rating: 3.53

www.plantsjournal.com

JMPS 2020; 8(4): 308-310

(C) 2020 JMPS

Received: 20-05-2020

Accepted: 25-06-2020

\section{Mahendra CP}

Associate Professor, Department of Botany, SW. PNKS Govt. P. G. College Dausa, Rajasthan, India
Corresponding Author: Mahendra CP

Associate Professor, Department of Botany, SW. PNKS Govt. P. G. College Dausa, Rajasthan, India

\section{Ethnomedicinal uses of plants of family Acanthaceae found in Dausa Rajasthan}

\section{Mahendra CP}

DOI: $\underline{\text { https://doi.org/10.22271/plants.2020.v8.i4d.1181 }}$

\section{Abstract}

The paper enumerate the ethnomedicinal uses of 11 plant species of 09 genera of family Acanthaceae used by local tribal people, Bhopa (village priest), headman and informants of Dausa district of Rajasthan. Information on the medicinal uses gathered from the tribals together with their botanical identity, local name and mode of administration are presented.

Keywords: Ethnomedicine, traditional, Dausa, Acanthaceae, tribe, meena, Rajasthan

\section{Introduction}

Though ethnobotany was almost unheard word in India in middle of last century yet it deals with study of traditional and indigenous knowledge about man-plant relationships which exist since birth of man on this earth ${ }^{[1]}$. Traditional ethnomedicinal studies have in recent years received much attention due to their wide local acceptability and clues for new or lesserknown medicinal plants ${ }^{[2]}$. Ethnomedicine is an area of research that deals with medicines derived from plants, animals, minerals etc. used in the treatment of various diseases and ailments ${ }^{[3]}$. Ethnomedicine includes indigenous beliefs, concepts, knowledge and practices among the ethnic group, folk people or race for preventing, lessening or curing disease or pain. Out of 20,000 medicinal plants of the world, India contributes about 15 per cent $(3000-3500)$ medicinal plants. About 90 per cent of these are found growing wild in different climatic regions of the country. Out of 3000 medicinal plants occurring in India, about 200 species are used in bulk quantities as articles of commerce ${ }^{[4]}$. Significant ethnobotanical/ethnomedicinal research has been done by several workers in India and in Rajasthan ${ }^{[5-20]}$.

Acanthaceae is a large cosmopolitan family of $c a .250$ genera and 2500 species distributed mostly in the tropical and subtropical areas of the world. The plants are Paleotropical, Neotropical cape and Australian. They are centered on Indo-Malaysia, Asia, Africa, Brazil and Central America. Medicinally very important family includes about 68 genera and 250-300 species are found throughout India while in Rajasthan this family is represented by 30 genera and 81 species. The family has a large number of ornamental and medicinal plants. They are mostly herb shrub and climbers. A large number of crude drugs used in Ayurvedic system employ plants of family Acanthaceae.

The district Dausa is situated in the north eastern region of Rajasthan, a region widely known as Dhundar and lies between $26^{\circ} 23^{\prime}$ to $27^{\circ} 15^{\prime} \mathrm{N}$ latitude and $76^{\circ} 06^{\prime}$ to $77^{\circ} 02^{\prime} \mathrm{E}$ longitude. The total area of the district is $3414.28 \mathrm{~km}^{2}$ which is $0.99 \%$ of the area of state (Fig.1) and surrounded by 06 districts viz., Jaipur, Tonk, Alwar, Bharatpur, Karauli and Swaimadhopur. The total population of district is $16,34,409$ out of which 2,01,793 urban and 14,32,616 rural populations as per census $2011^{[21]}$. The soil of district is yellowish to dark brown with fine texture generally suitable for all types of crops. It is characterized by dry climate with the hot season. The maximum temperature is $47^{\circ} \mathrm{C}$ and minimum $4{ }^{\circ} \mathrm{C}$. Total annual rainfall varies from $450 \mathrm{~mm}$ to $670 \mathrm{~mm}$. Agriculture practices mostly depends on monsoon rainfall. The district dominated by Meena tribe and other backward caste Gujar and Mali. 


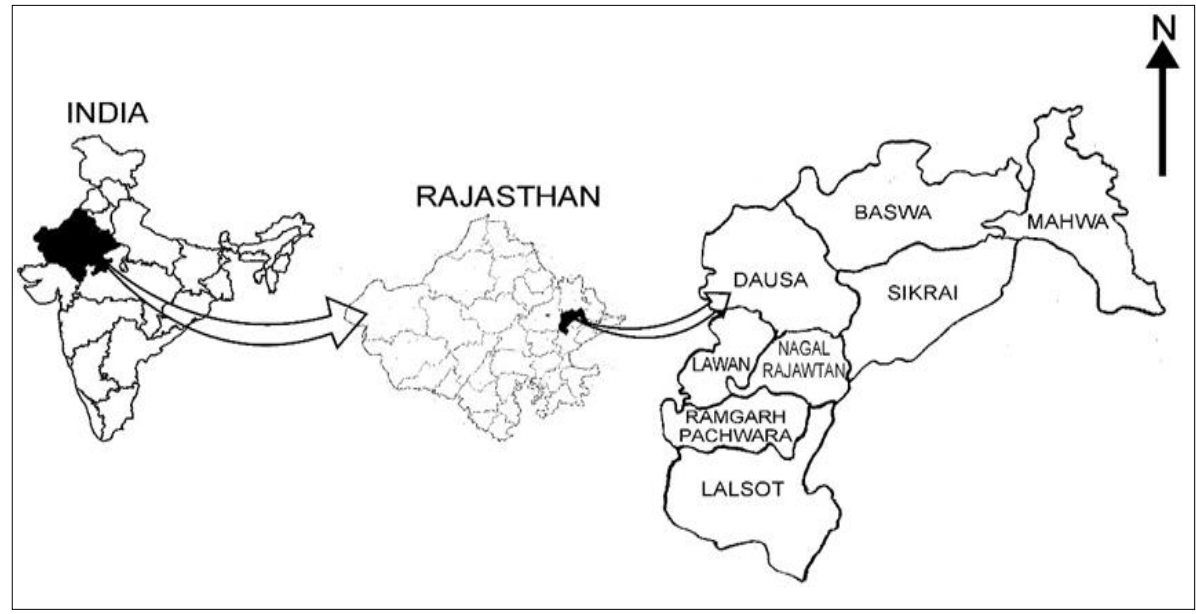

Fig 1: Map of the study area

\section{Methodology}

Plant material collected from surveyed area. Plant specimens were identified consulting various flora, taxonomic books, ethnobotany and medicinal plants books ${ }^{[22-39]}$. Collected plants were deposited in Herbarium, Department of Botany, University of Rajasthan, Jaipur and assigned RUBL, numbers. Detailed ethnomedicinal investigation was conducted on medicinally important 09 genus and 11 species of family Acanthaceae found in Dausa district. The plants are viz., Adhatoda vasica Nees (Syn. Justicia adhatoda, Adhatoda zeylanica), Barleria prionitis Linn, Barleria cristata Linn
(Syn. B. ciliata Roxb., B. dichotoma Roxb., B. laciniata Wall.) Blepharis repens (Vahl) Roth., Elytraria acaulis Lindau (Syn. E. crenata Vahl; Tubiflora acaulis Kuntze.), Hygrophila aurculata (Schum) Heines, Indoneesiella echioides (L.) Sreem, Lepidagathis cristata Willd, Lepidagathis trinervis Nees, Peristrophe bicalyculata Nees (Syn. P. paniculata (Forrsk.) Brummitt), Rungia repens (Linn.) Nees (Syn. Justicia repens Linn.).

\section{Enumeration}

Table 1: Ethnomedicinal Uses of Plants of Family Acanthaceae

\begin{tabular}{|c|c|c|c|c|}
\hline \begin{tabular}{|c|} 
S. \\
No.
\end{tabular} & Name of Plant & $\begin{array}{l}\text { Local } \\
\text { Name }\end{array}$ & $\begin{array}{l}\text { Plant Part (s) } \\
\text { Used }\end{array}$ & Uses \\
\hline 1 & $\begin{array}{l}\text { Adhatoda vasica Nees Syn. Justicia } \\
\text { adhatoda L., Adhatoda zeylanica Medic }\end{array}$ & Adusa & \begin{tabular}{c|} 
All parts \\
especially leaves
\end{tabular} & $\begin{array}{l}\text { Decoction of leaves along with jaggery and water are kept in an } \\
\text { earthen pot for a month by tribals and taken two teaspoonfuls twice } \\
\text { orally. This is highly beneficial in cure of tuberculosis. }\end{array}$ \\
\hline 2 & $\begin{array}{c}\text { Barleria prionitis L. subsp. prionitis var. } \\
\text { prionitis }\end{array}$ & Vajradanti & $\begin{array}{r}\text { All } \\
\text { especia }\end{array}$ & $\begin{array}{l}\text { Leaf decoction is given for the treatment of cough; roots and leaves } \\
\text { chewed to relieve toothache and bodyache. }\end{array}$ \\
\hline 3 & $\begin{array}{l}\text { Barleria cristata } \text { L. Syn } \text { B. ciliata } \text { Roxb., } \\
\text { B. dichotoma Roxb., B. laciniata Wall. }\end{array}$ & Janti & \begin{tabular}{|c|} 
All parts \\
especially leaves
\end{tabular} & $\begin{array}{r}\text { The decoction of root is very useful } \\
\text { is useful in cough anc }\end{array}$ \\
\hline 4 & Rlonharic ronons (Vahl) Roth & -- & Leaves & Decoction of the leaves is taken orally for jointache. \\
\hline 5 & $\begin{array}{l}\text { Elytraria acaulis Lindau Syn E. crenata } \\
\text { Vahl; Tubiflora acaulis Kuntze. }\end{array}$ & $\begin{array}{l}\text { Pathar- } \\
\text { Chatta }\end{array}$ & Root anc & $\begin{array}{l}\text { Root of the plant crushed with garlic and salt and kept on the } \\
\text { affected teeth for curing teeth infections or troubles. Decoction of } \\
\text { leaves used for venereal diseases. }\end{array}$ \\
\hline 6 & $\begin{array}{c}\text { Hygrophila auriculata } \text { (Schum) Heines } \\
\text { (Syn. Barleria longifolia L., H. longifolia } \\
\text { Nees, Astercantha longifolia } \text { (L.), } \\
\text { Hygrophila spinosa T. Anders) } \\
\end{array}$ & $\begin{array}{c}\text { Kulakhara, } \\
\text { Oont- } \\
\text { katela }\end{array}$ & $\begin{array}{l}\text { Leaves and } \\
\text { Roots }\end{array}$ & $\begin{array}{c}\text { Dried leaf powder mixed with castor oil is applied twice a day till } \\
\text { the recovery on the affected parts to cure skin diseases; Ash of } \\
\text { aerial parts eaten with honey to remove kidney and urinary bladder } \\
\text { stone. }\end{array}$ \\
\hline 7 & $\begin{array}{c}\text { Indoneesiella echioides (L.) Sreem. Syn. } \\
\text { Justicia echioides L., Andrographis } \\
\text { echioides (L.) Nees in Wall. } \\
\end{array}$ & $\begin{array}{l}\text { Jodapatta } \\
\text { Pattar }\end{array}$ & Lea & $\begin{array}{l}\text { Leaf paste is applied on the affected areas of a skin. This plant is } \\
\text { beneficial in skin diseases. }\end{array}$ \\
\hline 8 & Lepidagathis cristata Wild. & & Whole Plant & It is bitter herb \\
\hline 9 & Lepidagathis trinervis Nees & $\begin{array}{l}\text { Pather- } \\
\text { phor }\end{array}$ & Whole Plant & $\begin{array}{l}\text { One tea spoonful of the whole plant decoction is given once daily } \\
\text { for fortnight and one tea spoonful of root juice or powder is given } \\
\text { twice a day for two months to cure piles. }\end{array}$ \\
\hline 10 & $\begin{array}{l}\text { Peristrophe bicalyct } \\
\text { paniculata (Forr }\end{array}$ & Atrilal & Whole Plant & $\begin{array}{l}\text { Two drops of juice of freshly collected and washed leaves is poured } \\
\text { into eyes twice daily in cases of conjunctivitis for 2-3 days. }\end{array}$ \\
\hline 11 & $\begin{array}{c}\text { Rungia repens }(\mathrm{L} .) \text { Nees Syn. Justicia } \\
\text { repens (L.) }\end{array}$ & मान & hole Plant & $\begin{array}{c}\text { Four teaspoonful of tuberous root decoctions are given twice daily } \\
\text { for the treatment of gonorrhea. }\end{array}$ \\
\hline
\end{tabular}

\section{Results and Discussion}

During the present investigation authors have reported medicinally important 09 genus and 11 species of family Acanthaceae used by tribals in the district in their day to day life. The data on ethnomedicinal plants such as the botanical name, local name, plant part(s) used and the medicinal uses are presented (Table 1). The plants enumerated in the text are wild and they have proved handy and easily available remedial material which quick result. It has been observed that the folklore and tribal herbalist still depend upon wild plants around them for meeting their needs and posses good knowledge of the medicinal uses of such plants. Due to constant association with the forest environment, they have evolved knowledge by trial and error and have developed 
their own way of diagnosis and treatment of different ailments. These plants are being used to treat various ailments such as tuberculosis, cough, fever, skin diseases, venereal diseases, sores, gonorrhea, conjunctivitis, anaemia, stone, toothache, bodyache, and inflammation. Now a day, population is expanding in villages, younger generations tend to discard their traditional life style therefore, much of this wealth of knowledge is being lost as the traditional culture is disappearing. Hence, documentation of traditional practices of herbal medicine will be coherence in future. With the help of earlier studies and the present day research data its exploration shows that these ethnobotanical studies can be greatly beneficial to human race for treating disease with cheap and best non side effect solutions.

\section{Acknowledgement}

The author is grateful to University Grants Commission, CRO, Bhopal for financial support and sincere thanks to people, headman and informants of the study area to provide valuable information about uses of above mentioned plants.

\section{References}

1. Jain SK. The Widening Panorama of Ethnobotany in India, J Indian Bot. Soc. 2019; 98(3\&4):98-102.

2. Tripathi YC. Ethnomedicinal Treasure of Tribal Rajasthan, J Non-Timber for Products. 2000; 7(2):77-84.

3. Weiner MA. Ethnomedicine in Tonga, Econ. Bot. 1971; 25:423-450.

4. Singh HB. Alternate source for some conventional drug plants of India: In Ethnobotany and Medicinal plants of Indian subcontinent. ed by J.K. Maheshwari. Scientific Publishers, Jodhpur, 2000, 109-114.

5. Meena KL, Yadav BL. Some traditional ethnomedicinal plants of southern Rajasthan, Indian $\mathbf{J}$ of Traditional Knowledge. 2010; 9(3):471-474.

6. Sharma A, Kumar A. Acanthaceae: Taxonomy and uses in traditional medicinal system, World Journal of Pharmaceutical Research. 2016; 5(7):403-412.

7. Mishra A, Kumar A. Studies on Ayurvedic crude drugs for the cure of urinary tract stones, Int. J Mendel. 2000; 18(1-2):41-42.

8. Sharma LK, Kumar A. Searching for anti-cancer drugs in traditional medicines, International Journal of Mendel. 2000; 17(3-4):77-78.

9. Sharma S, Kumar A. Studies on anti-paralytic crude drugs used in Ayurvedic system, Int. J Mendel. 2001; 18:33-34.

10. Katewa SS, Chaudhary BL, Jain A, Galav P. Traditional uses of plant biodiversity from Aravalli hills of Rajasthan, Ind. J Trad. Knowl. 2003; 2(1):27-39.

11. Seema, Kumar A. Importance of medicinal plants in present scenario, Int. J Mendel. 2004; 21(1-2):29-30.

12. Katewa SS, Galav PK. Additions to the traditional folk herbal medicines from Shekhawati region of Rajasthan, Ind. J Trad. Knowl. 2006; 5(4):494-500.

13. Mahlawat S, Kumar A. Traditional medicinal plants used by tribal people of Rajasthan in human ailments, Int. J Mendel. 2005a; 22(1-2):47-48.

14. Meena MC, Meena RK, Patni V. Ethnobotanical studies of Citrullus colocynthis (Linn.) Schrad. An Important threatened medicinal herb, Journal of Medicinal Plants Studies. 2014; 2(2):15-22.

15. Sharma A, Sharma1 A, Kumar VR, Kumar A. Selected medicinal plants of order Lamiales used in traditional medicine, American Journal of Pharmacy and Health
Research. 2015; 3(1):31-38.

16. Kumar V, Kotia A. Present Ethnobotanical Aspect of Tribal Communities of Rajasthan, Heritage Amruth. 2014; 10(6):19-22.

17. Jain AK, Wagh VV, Kadel C. Some ethnomedicinal plant species of Jhabua district, Madhya Pradesh, Indian J of Traditional Knowledge. 2011; 10(3):538-540.

18. Mhatre K, Shinde R. Ethnobotanical investigations of family Asteraceae among the tribe of Raigad district of Maharashtra state, India, Journal of Indian Bot. Soc. 2018; 97(3):72-76.

19. Mishra L, Dixit Y, Singh M. Studies on ethno-medicinal plants of Shekhawati region Rajasthan, having hypoglycemic properties, Indian Journal of Fundamental and Applied Life Science. 2014; 4(2):62-66.

20. Jain A, Katewa SS, Galav P, Nag A. Some therapeutic uses of biodiversity among the tribals of Rajasthan, Indian Journal of Traditional Knowledge. 2008; 7(2):256262.

21. District Statistics Blueprint. Economics and Statistics Directorate, Rajasthan, Jaipur, 2016, 1-116.

22. Hooker JD. Flora of British India, Reeve \& Co. Kent. $1885 ; 5: 582 \mathrm{~L}$.

23. Kirtikar KR, Basu BD. Indian Medicinal Plants. Lalitmohan Basu, Allahabad, India, 1918, I-IV (Rep. ed. 1981).

24. Maheshwari JK. Flora of Delhi, CSIR, New Delhi, 1963.

25. Sharma S. An enumeration of the flora of Jaipur district in Rajasthan. University of Rajasthan Stud. In Botany, Jaipur, 1974.

26. Dey KL. The Indigenous Drugs of India. Calcutta, 1976, (Res. ed. 1984).

27. Sharma S, Tiagi B. Flora of Northeast Rajasthan. Kalyani Publications, New Delhi, 1979.

28. Jain SK. Methods and Approaches in Ethnobotany. Society of ethnobotany, Lucknow, 1989.

29. Bhandari MM. Flora of Indian Desert. Scientific Publishers, Jodhpur, 1990.

30. Shetty BV, Singh V. Flora of Rajasthan. Botanical Survey of India, 1991, 2.

31. Bhattacharyya B, Johri BM. Flowering Plants, Taxonomy and Phylogeny. Narosa Publishing House, New Delhi, 1998.

32. Singh V. Flora of Banswara district, Rajasthan. Bot. Surv. India. Howrah, 1983.

33. Sivarajan VV. Introduction to Principles of Plant Taxonomy. Oxford \& IBH, New Delhi, 1984.

34. Ambasta SP, Ramachandran K, Kashyapa K, Chand R. The useful plants of India. CSIR, New Delhi, 1993.

35. Warrier PK, Nambiar VKP, Ramankutty C. Indian Medicinal Plants. Orient Longman, Madras, 1993.

36. Sivarajan VV, Balachandran I. Ayurvedic Drugs and their Plant Sources. Oxford \& IBH Publishing Co. Pvt. Ltd. New Delhi, 1994.

37. Hajra PK, Rao RR, Singh DK, Uniyal BP. Flora of India. B.S.I. Calcutta, 1995.

38. Trivedi PC. Indigenous Ethnomedicinal Plants. Pointer Publishers, Jaipur, 2009.

39. Joshi P. Ethnobotany of Primitive Tribes in Rajasthan. Printwell, Jaipur, 1995. 